\title{
Zum Bernsteinschen Äquivalenzsatz
}

von

\section{H. A. Jung (Köln)}

$A, B$ seien beliebige Mengen. Eine Abbildung $\varphi$ wird in dieser Note als Relation zwischen $A$ und $B$ aufgefaßt: $\varphi \subseteq A \times B$. Ein $\varphi^{\prime} \subseteq \varphi$ heißt Teilabbildung von $\varphi$.

Die Abbildung $\varphi$ heißt gesättigt bei $A$, wenn $\left|\varphi\left(A^{\prime}\right)\right| \geqslant\left|A^{\prime}\right|$ für jedes endliche $A^{\prime} \subseteq A$ gilt; $\varphi$ heißt gesättigt bei $B$, wenn $\varphi^{-1}$ bei $B$ gesättigt ist: $\left|\varphi^{-1}\left(B^{\prime}\right)\right| \geqslant\left|\overline{B^{\prime}}\right|$ für jedes endliche $B^{\prime} \subseteq B$.

J. König bewies (in [2], vgl. auch St. Banach [1]) die folgende Verschärfung des Äquivalenzsatzes von Bernstein (ohne Benutzung des Auswahlpostulates):

$\varphi_{1}$ sei eineindeutige Abbildung von $A$ in $B, \varphi_{2}$ eineindeutige Abbildung aus_ $A$ a uf $B$. Dann gibt es eine eineindeutige $A b b i l d u n g ~ \varphi^{\prime}$ von $A$ auf $B$ mit $\varphi^{\prime} \subseteq \varphi_{1} \cup \varphi_{2}$.

Wir beweisen allgemeiner, ebenfalls ohne Benutzung des Auswahlpostulats:

SATz 1. $\varphi_{1}, \varphi_{2}$ seien eineindeutige Abbildungen aus $A$ in $B$. Es gibt genau dann eine eineindeutige Abbildung $\varphi^{\prime}$ von $A$ auf $B$ mit $\varphi^{\prime} \subseteq \varphi_{1} \cup \varphi_{2}$ $\left(\varphi^{\prime}\right.$ Teilabbildung von $\left.\varphi_{1} \cup \varphi_{2}\right),{ }_{-}$wenn $\varphi_{1} \cup \varphi_{2}$ bei $A$ und bei $B$ gesättigt ist.

Zugleich ergibt sich:

SATZ 2. $\varphi_{1}, \varphi_{2}$ seien eineindeutige Abbildungen aus $A$ in $B$. Es gibt genau dann eine eineindeutige Abbildung $\varphi^{\prime}$ von $A$ in $B$ mit $\varphi^{\prime} \subseteq \varphi_{1} \cup \varphi_{2}$, wenn $\varphi_{1} \cup \varphi_{2}$ bei A $A_{2}$ gesättigt ist.

Beweis. Die Notwendigkeit der Bedingungen in Satz 1 und Satz 2 ist selbstrerständlich. Zum Beweis, daß diese hinreichend sind, setzen wir voraus, daß $\varphi_{1}$ und $\varphi_{2}$, weiter $A$ und $B$ elementfremd sind. (Der allgemeine Fall läßt sich durch einfache formale Abänderungen darauf zurückführen.)

$A, B$ und $\varphi_{I} \cup \varphi_{2}$ definieren einen gerichteten Graphen $G$ mit der Eckenmenge $A \cup B$, der Kantenmenge $\varphi_{1} \cup \varphi_{2}$. Die Begriffe Weg, Komponente und Faktor werden vorausgesetzt. $\gamma(a)$ bzw. $\delta(b)^{\ddagger}$ bezeichne die

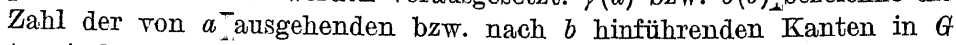
$(a \in A, b \in B)$. Es ist ein Faktor $\bar{G}$ von $G$ zu konstruieren mit $\bar{\gamma}(a)=1$, 
$\bar{\delta}(b)=1(a \in A, b \in B)$ bzw. (bei Satz 2) $\bar{\gamma}(a)=1, \bar{\delta}(b) \leqslant 1 \quad(a \in A, b \in B)$. Wir konstruieren $\bar{G}$ komponentenweise. $K$ sei also eine Komponente von $G$.

Da $\varphi_{1} \cup \varphi_{2}$ bei $A$ gesättigt ist, gibt es keine $a \in A$ mit $\gamma(a)=0$. Für ein $a_{0}$ aus $K$ gelte $\gamma\left(a_{0}\right)=1$. An $a_{0}$ liege eine Kante von $p_{1}$ (o.B.d.A.). Gibt es nun ein $a_{1}$ in $K$, woran keine Kante aus $\varphi_{1}$ stößt, so erschöpft ein Weg von $a_{0}$ nach $a_{1}$ alle Ecken und Kanten von $K$; also ist die Zahl der $a$ in $K$ größer als die der $b$ in $K$, somit $\varphi_{1} \cup \varphi_{2}$ nicht gesättigt bei $A$. An jedes $a$ von $K$ stößt also eine Kante von $\varphi_{1}$. An jedes $b$ von $K$ stößt eine Kante ron $\varphi_{1}$, da ein Weg ron $a_{0}$ nach $b$ eine ungerade Zahl von Kanten enthält, die abwechselnd zu $\varphi_{1}$ bzw. $\varphi_{2}$ gehören. Die Kanten in $K$ von $\varphi_{1}$ bilden also einen Faktor der Bedingung.

Für jedes $a$ von $K$ gelte $\gamma(a)=2$. Ist für ein $b$ von $K \delta(b)=0$, so besteht $K$ nur aus dieser Ecke, und $\varphi_{1} \cup \varphi_{2}$ ist nicht gesättigt bei $B$. In $K$ gebe es zwei Ecken $b_{1} \neq b_{2}$ mit $\delta\left(b_{1}\right)=\delta\left(b_{2}\right)=1$. Ein Weg von $b_{1}$ nach $b_{2}$ erschöpft alle Ecken und Kanten von $K$. Wie oben (für A) folgt, daß $\varphi_{1} \cup \varphi_{2}$ nicht bei $B$ gesättigt ist. Im Fall von Satz 2 bilden die Kanten von $\varphi_{1}$ in $K$ einen Faktor der Bedingung. Gilt für alle $b$ von $K \delta(b)=2$, so definieren die Kanten von $\varphi_{1}$ in $K$ einen Faktor der Bedingung. Schließlich gebe es genau ein $b_{0} \in B$ in $K$ mit $\gamma\left(b_{0}\right)=1$. An $b_{0}$ stoße eine Kante aus $\varphi_{1}$ (o.B.d.A.). Die Kanten von $\varphi_{1}$ in $K$ bilden dann einen Faktor der Bedingung. Damit sind Satz 1 und Satz 2 bewiesen.

\section{Literaturverzeichnis}

[1] J. König, Sur la théorie des ensembles, C. R. Acad. Sei. Paris 146 (1906), S. 110. [2] S. Banach, Un théorème sur les transformations liunivoques, Fund. Math. 6 (1924), p. 236.

[3] 0. Ore, Theory of graphs, AMS Colloquium Publications rol. 38, 1962.

Regu par la Rédaction le 28. 10.1963

\section{On regular extensions of operator systems}

by

\section{W. M. Z awa a owski (Warszawa)}

The aim of this note is to propose a slightly improved version of the extension theorem given by W. Stowikowski in this journal, [8].

I. An operator system is an ordered pair $(\boldsymbol{S}, \boldsymbol{X})$, where

a. $S$ is a semigroup with the unit element,

b. $\boldsymbol{X}$ is a commutative group,

c. with each element $A \in \boldsymbol{S}$ there is associated a subgroup $\boldsymbol{G}_{\boldsymbol{A}} \subset \boldsymbol{X}$, and with each pair $\boldsymbol{A} \in \boldsymbol{S}, x \in \boldsymbol{G}_{\boldsymbol{A}}$ there is associated an element $y \in \boldsymbol{X}$, which is called the composition of $A$ and $x, y=A x$, and

the map $A: \boldsymbol{G}_{\boldsymbol{A}} \rightarrow \boldsymbol{X}$ is a homomorphism of $\boldsymbol{G}_{\boldsymbol{A}}$ onto the whole group $\boldsymbol{X}$.

We do not assume the cancellation law for $\boldsymbol{S}$.

An operator system $(\boldsymbol{S}, \boldsymbol{X})$ is linear, if $\boldsymbol{X}$ is a linear space, and $x \in \boldsymbol{G}_{A}$ implies $\lambda x \in \boldsymbol{G}_{A}$, and $A(\lambda x)=\lambda A x$ for every sealar $\lambda$.

We may always reduce the theory of linear operator systems $(\boldsymbol{S}, \boldsymbol{X})$ to the theory of ordinary operator systems considering $\boldsymbol{X}$ a group, and enlarging $S$ to include all the operators of multiplication by a scalar. An operator system is regular, if

1. $G_{A}=\boldsymbol{X}$ for every $A \in S$, and

2. $A(B x)=(A B) x$, which means that if either member of this equality makes sense then the other does too and both are equal.

In regular operator systems composition is always feasible, and the semigroup operation is compatible with the operation of superposition of the maps $A: \boldsymbol{G}_{\boldsymbol{A}} \rightarrow \boldsymbol{X}$.

The notion of operator system was first introduced by Słowikowski in [6] and then described in detail in [8], but it lurks in all the papers cited. We follow the terminology of Stowikowski, but we do not require here a priori that the semigroup $\boldsymbol{S}$ be commutative, and we do not assume $a$ priori that the semigroup operation in $\boldsymbol{S}$ is identical with the superposition of its elements considered as maps $\boldsymbol{A}: \boldsymbol{G}_{\boldsymbol{A}} \rightarrow \boldsymbol{X}$, as it is done in [5]. Dropping these two requirements we avoid some inconvenient conditions on domains $\boldsymbol{G}_{\boldsymbol{A}}$. An important example of a linear operator 